\title{
White Adipose Tissue and Circadian Rhythm Dysfunctions in Obesity: Pathogenesis and Available Therapies
}

\author{
Eleonora S. Pagano ${ }^{a}$ Eduardo Spinedi $^{\text {b Juan J. Gagliardino }}{ }^{b}$ \\ anstitute on Biomedical Research (BIOMED-UCA-CONICET), Faculty of Medical Sciences, Pontifical Catholic \\ University, Buenos Aires, and ${ }^{\mathrm{b}}$ Centre of Experimental and Applied Endocrinology (UNLP-CONICET-FCM), La Plata \\ Medical School, La Plata National University, La Plata, Argentina
}

\section{Keywords \\ Adipose tissue mass expansion · Chronobiology · Obesity prevention/treatment · Clock genes · Adipose tissue dysfunction - Obesity pathogenesis - Glucose regulation . Central/peripheral clocks · Nutrients · Feeding time · Chronotherapeutic approach}

\begin{abstract}
A combined neuroendocrine, metabolic, and chronobiological view can help to better understand the multiple and complex mechanisms involved in obesity development and maintenance, as well as to provide new effective approaches for its control and treatment. Indeed, we have currently updated data on the whole adipogenic process involved in white adipose tissue (WAT) mass expansion, namely due to a mechanism whereby WAT cells become hypertrophic, thus inducing a serious local (WAT) inflammatory condition that in turn, will impair not only the cross-talk between the hypothalamus and the WAT, but also favoring the development of deep and widespread neuroendocrine-metabolic dysfunction. Moreover, we also have revisited the circadian clock genes involved in dysfunctional WAT mass expansion and the mechanisms that may lead to obesity development,
\end{abstract}

including early metabolic dysfunctions, enhanced oxidative stress and distorted energy homeostasis. The epigenetic changes of clock genes driving metabolic disease and obesity development have also been included in this review. Finally, we have also underlined the relevance of metabolic homeostasis regulation by central and peripheral organ clocks, sleep disturbances, nutrients, and feeding time, as key factors in obesity development as well as both, classical and chronotherapeutic approaches for its prevention and treatment.

(c) 2016 S. Karger AG, Basel

\section{Introduction}

Although obesity is a preventable disease, its prevalence is continuously increasing worldwide [1]; and because it is frequently associated with other cardiovascular risk factors and high mortality, obesity has become an important public health problem and a heavy socioeconomic burden for the overall society $[1,2]$.

All authors contributed equally to the design, draft, and revision of this review.

\section{KARGER}

(c) 2016 S. Karger AG, Basel

E-Mail karger@karger.com

www.karger.com/nen
Eduardo Spinedi, $\mathrm{PhD}$

CENEXA (UNLP-CONICET-FCM)

La Plata Medical School, La Plata National University

La Plata 1900 (Argentina)

E-Mail spinedi@ cenexa.org 
Overweight and obesity are defined as abnormal or excessive fat accumulation and though not generally accepted, its diagnosis is still based on an anthropometric concept (body mass index; BMI). In fact, many incongruities weaken the value of BMI as a cornerstone of the current obesity classification system, but the reliance upon this simple tool still goes on [3].

The excessive fat accumulation, either in white adipose tissue (WAT) or other organs, is the consequence of hypertrophy and hyperplasia of white adipocytes in a context of positive energy balance [4]. This balance is controlled mainly at the hypothalamic level by a complex circuitry of orexigenic and anorexigenic signals [5] and by an endogenous clock that sets a circadian rhythm of appetite-satiety, a function highly affected by modern life habits [6].

WAT is currently recognized as an active endocrine organ that synthesizes and releases multiple adipokines that also plays several paracrine and autocrine roles [7]. These adipokines, together with those produced by infiltrating macrophages (cytokines), also exert proinflammatory activity in pathological conditions [7]. Consequently, obesity is the result of a multifactorial combination of genetic background, metabolic, endocrine, inflammatory and circadian dysfunctions, whose longterm maintenance is favored by behavioral disorders [1].

Considering the key role of energy homeostasis for the normal development and maintenance of body functions, its control must be ensured by a complex self-tuned servo-mechanism established between body organs with participation of many hormones as main signals as schematically shown in Figure 1. Indeed, food intake triggers the release of several gut hormones (glucagon like peptide-1 [GLP-1], glucose-dependent insulinotropic polypeptide, cholecystokinin, oxyntomodulin) that inhibit/ slow gastric emptying/acid release, strongly modulate endocrine pancreas function (enhance insulin and decrease glucagon secretion) and inhibit brain neuropeptide Y, peptide YY and GLP-1. Moreover, high serum insulin levels will additionally impact on the hypothalamus (satiety effect) and WAT (enhanced leptin [LEP] release), thus summing their activities to the above-mentioned ones to reinforce appetite inhibition. This complex modulator interaction also affects glycemia homeostasis. Alteration in these fine-tuned mechanisms causes serious metabolic diseases, such as obesity and type 2 diabetes. Analyzing how some of these peripheral signals interact with hypothalamic neurons (mainly located at the arcuate nucleus $[\mathrm{ARC}]$ ) involved in the control of the brain appetite/satiety circuitry, indicates that WAT-derived LEP stimulates the melanocortinergic system and neurons producing strong anorexigenic peptides (proopiomelanocortin and cocaine- and amphetamine-regulated transcript) peptide. Interestingly, insulin shares a similar anorectic effect by acting directly (through its binding to insulin receptor) upon the same neurons. Both signals act in ARC neurons through their binding to their active receptors (the long isoform of LEP receptor [ObRb] and insulin receptor, respectively). As mentioned above, gutreleased peptide YY and GLP-1 impact upon ARC neurons together with insulin and LEP, inhibiting orexigenic activities, such as neuropeptide Y- and agouti-related protein-producing neurons.

We may also assume that this complex mechanism could be easily altered by environmental factors mainly when they act repeatedly and over a long period of time. In this context, the aim of this review is to briefly analyze the role of 2 of them in the development of obesity: WAT development and its dysfunction associated with impairment of its circadian control. Within this scope, we thereafter propose a potential chronobiological therapeutic approach for its effective prevention, control, and treatment.

\section{Looking for a Dysfunctional Starting Point}

Because obesity is tightly related to WAT mass, it is reasonable to identify its origin and function when trying to understand its pathophysiological basis. Accordingly, we will start briefly describing the adipogenic process, its regulation and dysfunction.

Expansion and renewal of the adipocyte pool in WAT depends on the adipogenic process. This process includes: (a) the commitment of mesenchymal stem cells (MSCs) [8] into adipocyte precursor cells (APCs) located within the adipose stromal cell (ASCs) population [9], thus acquiring adipogenic potential and restricting them to adipocyte fate, and (b) a final differentiation of APCs to mature adipocytes (Fig. 2). APCs are similar to bone marrow MSCs [10-12] and support vascularization as mural/adventitial cells secreting angiogenic factors $[13,14]$. APCs have been identified within the adipose stromal cell population based on the expression of mesenchymal markers, such as platelet-derived growth factor receptor- $\beta$ (PDGFR $\beta$, aka CD140b) and pericyte markers [15-18].

APC differentiation is highly modulated by endocrine and metabolic factors such as insulin and glucocorticoid (GC) working either individually or in combination [19]. On the other hand, WAT mass expansion could result 


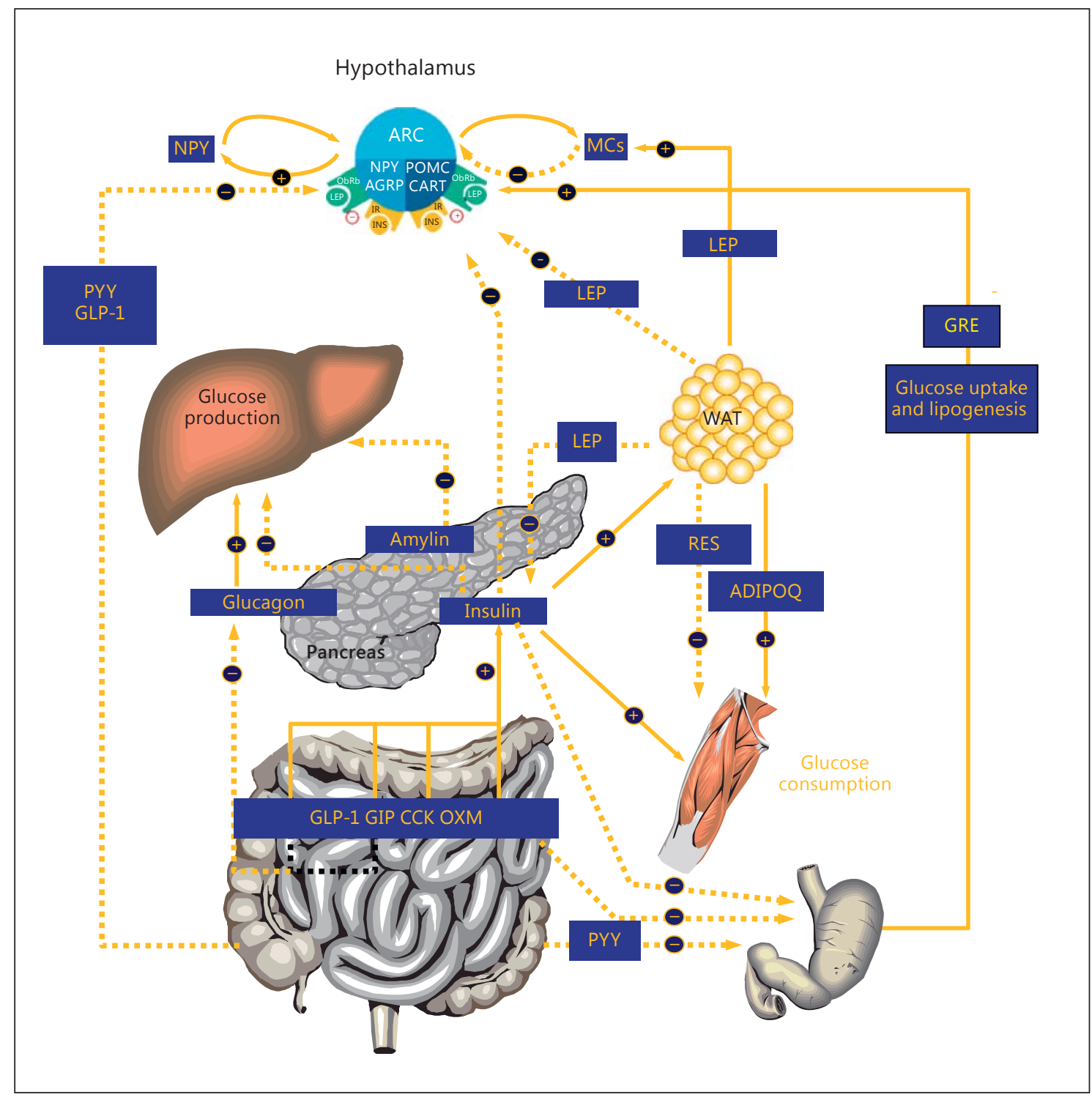

Fig. 1. Interrelationship between signals from the hypothalamus and peripheral tissues involved in maintaining energy homeostasis. A schematic model showing the complex net of neuroendocrine and metabolic signals that the system employs to assure tight control of energy homeostasis. To attain such control, peripheral tissues release different products that settle a feedback system among them as well as with the hypothalamus. ARC, hypothalamic arcuate nucleus; NPY, neuropeptide Y; CART, cocaine- and amphetamine-regulated transcript; ObRb, long isoform of leptin re-

from either cell tissue hyperplasia (increased number of normal mature "small-size" adipocytes) or their hypertrophy (increase in the size of dysfunctional adipocytes). Normal adipogenesis (newly generated "small-size" adipocytes), occurs when WAT mass needs to be recovered, ceptor; LEP, leptin; IR, insulin receptor; INS, insulin; MCs, melanocortin system; PYY, peptide YY; GLP-1, glucagon like peptide-1; GRE, glucose regulatory elements; WAT, white adipose tissue; RES, resistin; ADIPOQ, adiponectin; GIP, glucose-dependent insulinotropic polypeptide; CCK, cholecystokinin; OXM, oxyntomodulin (for detailed description see Introduction). Solid and dotted arrows indicate stimulation and inhibition, respectively. Adapted from Gagliardino [153].

for example during/after a long-term period of negative energy balance. In these circumstances, the new adipocytes develop a normal function. On the other hand, in rats with chronic high serum levels of LEP, GC and insulin, their visceral WAT undergoes a marked reduction in 


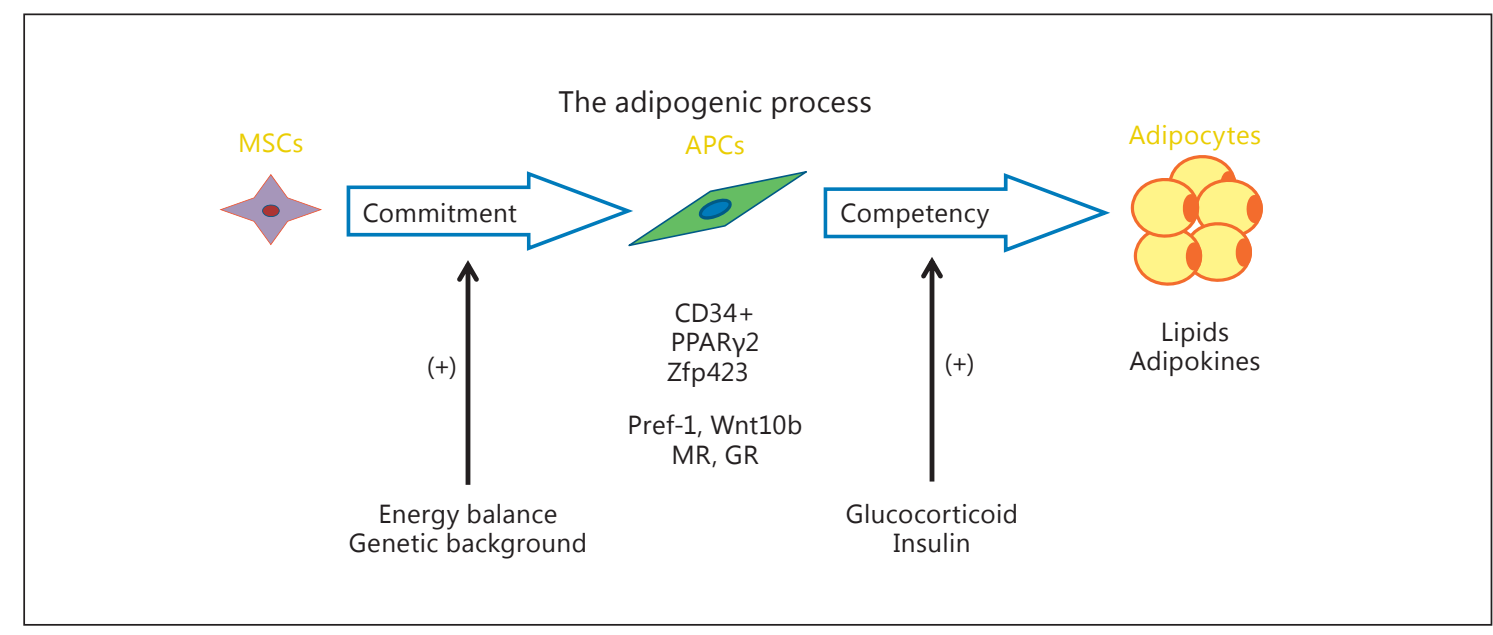

Fig. 2. Adipogenesis. The adipogenic process involves 2 sequential steps: commitment of mesenchymal stem cells (MSCs) into adipose tissue precursor cells (APCs), acquiring the adipogenic potential and restricting them to the adipocyte linage, followed by terminal adipocyte differentiation. In the first step, APCs begin to express CD34, a cell surface antigen that distinguishes between adipogenic and nonadipogenic cell subpopulations. The CD34+ cell subpopulation expresses almost exclusively the transcriptional factor Zfp423, which in turn activates the basal expression of PPAR-2, a key proadipogenic signal that assures APC conversion into adipocytes. The differential expression of both transcription- al factors determines the cell's ability to differentiate into adipocytes upon the action of adipogenic stimulus (competency). Thereafter, and in response to the adipogenic stimuli (mainly endogenous glucocorticoid and insulin), APCs differentiate into mature adipocytes, cells characterized by intracellular lipid storage, adipokine production and insulin responsiveness. CD34, cell surface antigen distinguishing adipogenic from nonadipogenic cells; PPAR $\gamma$-2, peroxisome proliferator receptor- $\gamma-2$; Zfp423, zinc finger protein 423; Pref-1, preadipocyte factor-1; Wnt10b, wingless type MMTV integration site family member 10b; MR, mineralocorticoid receptor; GR, glucocorticoid receptor. the number of compromised APCs, namely white APCs (WAPs), and a significant delay in their capacity to differentiate into mature adipocytes [20]; consequently, the local WAT pad becomes full of dysfunctional-hypertrophic adipocytes [21], a situation reverted by normalization of the high endogenous GC milieu [21].

When WAT mass increases by adipocyte hypertrophy, these large-size adipocytes develop a secretory dysfunction characterized by overproduction (synthesis and release) of adipokines that decrease tissue sensitivity to insulin, promote oxidative stress (OS), and display proinflammatory effects (LEP, resistin, tumor necrosis factor- $\alpha$, plasminogen activator inhibitor type 1, interleukin-1 [IL1], IL-6); conversely, they release lower amounts of adiponectin (ADIPOQ; an insulin-sensitizing adipokine) [22].

OS (either local or as part of a general one) also impacts on large-size adipocyte function such as their own insulin sensitivity, thus establishing a vicious circle that perpetuates their dysfunction [23]. The multifactorial adipocyte dysfunction and the participation of macrophages (WAT infiltration) in the whole process result in other tissues' dysfunction that affects the overall homeostasis as summarized in Figure 3. Within this scenario, 3 main dysfunctions play a key pathogenic role: (1) enhanced release of LEP that impairs tissue sensitivity to insulin (insulin resistance [IR]) [24], (2) the prolonged high serum LEP levels that induce down-regulation of LEP receptors $(\mathrm{ObRb})$ at pancreatic $\beta$ - and $\alpha$-cell level (as in other tissues as well), thus impairing its negative feedback mechanism on both insulin and glucagon secretions [25, 26], and (3) increased release of proinflammatory adipokines (mainly tumor necrosis factor- $\alpha$, IL- 1 , and IL-6) that acting on the medial basal hypothalamus, activate the hypothalamo-pituitary-adrenal axis with the consequent increased release of GCs [27, 28]. This multifactorial metabolic and endocrine dysfunctions lead to overall insulin and LEP resistance (Fig. 4) as well as to a pro-oxidative and proinflammatory states (Fig. 3) that reinforce WAT and hypothalamic dysfunctions, setting a serious impairment in the energy homeostasis [29, 30].

Regarding the modulatory effect of metabolism and dietary composition on APC differentiation, it has been shown that 8-week fructose-rich diet (FRD) administration induces several alterations, such as high plasma levels of insulin, LEP and triglyceride associated with increased mass of retroperitoneal adipose tissue (RPAT). Indeed, 


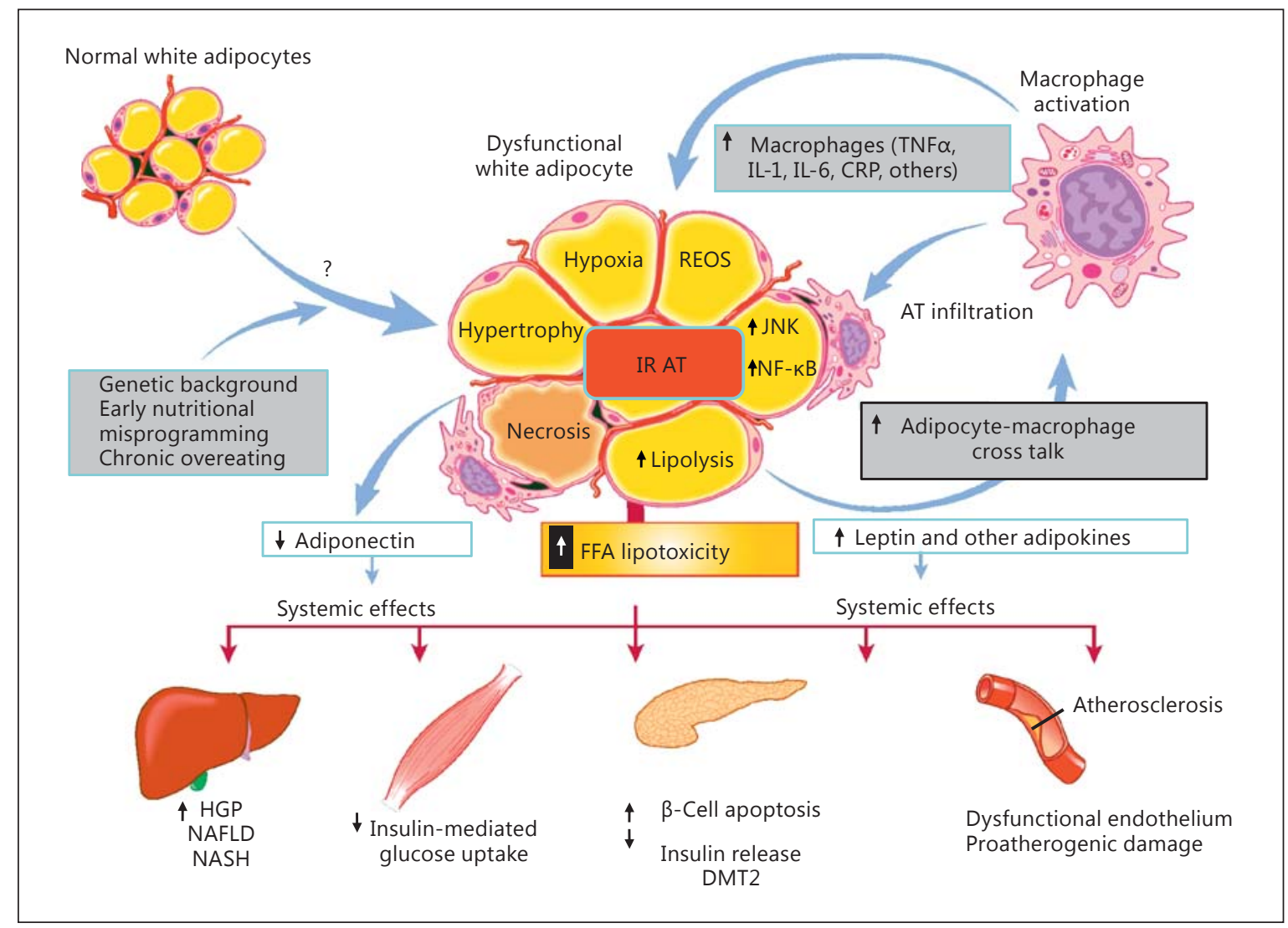

Fig. 3. White adipose tissue (WAT) and inflammation: neuroendocrine-metabolic consequences. A combination of genetic background, unhealthy diet, and sedentary lifestyle can induce hypertrophic increase in WAT mass associated with macrophage infiltration, leading to an abnormal pattern of adipokine production/ release. Enhanced WAT-derived leptin release, in turn, impairs tissue sensitivity to insulin (insulin resistance, IR). Thereafter, the prolonged hyperleptinemia could induce ObRb downregulation, namely at the pancreatic ( $\beta$ - and $\alpha$-cell) level, thus impairing its negative feedback mechanism on both insulin and glucagon secretions; moreover, the increased release of proinflammatory signals
(TNF, IL-1, IL-6, and C-reactive protein [CRP], among others) will worsen several functions. In fact, overall WAT dysfunction promotes multiple endocrine-metabolic dysfunctions, such as insulin resistance (IR), enhanced reticulum endoplasmic oxidative stress (REOS), enhanced lipolytic activity, cell hypoxia, and apoptosis. These alterations affect multiple organs, namely HPA axis, liver, muscle, endocrine pancreas, and endothelium functions. FFA, free fatty acid; JUNK, Janus kinase; NF- $\kappa \mathrm{B}$, nuclear factor- $\kappa \mathrm{B}$; HGP, hepatic glucose production; NAFLD, nonalcoholic fatty liver disease; NASH, nonalcoholic steatohepatitis; DMT2, diabetes mellitus type 2. Adapted from Cusi [154]. the RPAT pad has 2 adipocyte populations: one similar to and another larger than the ones identified in the normal (control) group, thus suggesting that this AT pad mass expansion could result from a combination of newly generated adipocytes (adipogenesis) and hypertrophy of the existing ones [22, 31-33].

As mentioned before, the adipogenic process involves 2 sequential steps: commitment of MSCs into APCs, acquiring adipogenic potential and restricting them to the adipocyte linage, followed by terminal adipocyte differentiation [34]. In the first step, APCs begin to express CD34, a cell surface antigen that distinguishes between adipogenic and nonadipogenic cell subpopulations [35]. This CD34+ cell subpopulation expresses almost exclusively the transcription factor zinc finger protein 423 (Zfp423) [36], which in turn activates the basal expression of PPAR $\gamma-2$, a key proadipogenic signal that assures APC conversion into adipocytes [37]. The differential expression of both transcription factors determines the competency of APCs, i.e. a cell's capacity to differentiate into adipocytes upon the appropriate action of adipogenic stimuli [34]; these newly generated cells are characterized by intracellular lipid storage, adipokine production, and insulin responsiveness. 


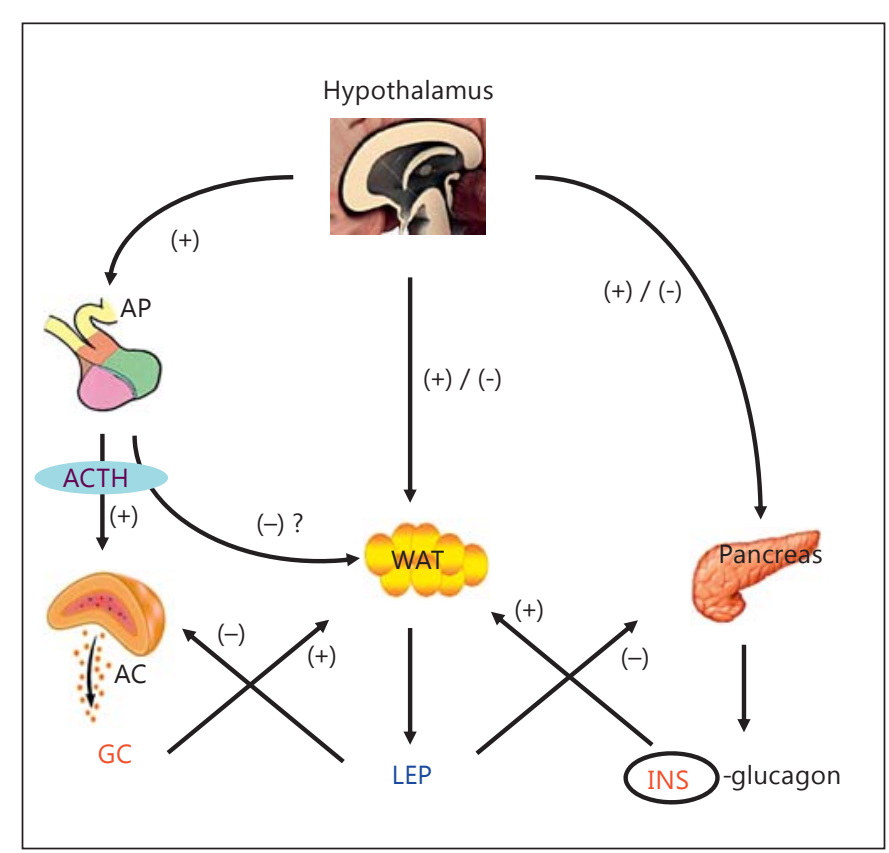

Fig. 4. Dysfunction of main endogenous adipogenic signals. Enhanced white adipose tissue (WAT) mass, at the expenses of adipocyte hypertrophy, results in hyperleptinemia that, if established for a long time, could result in a leptin-resistant state. As a result of the lack of the leptin-inhibiting effect, 2 system functions became mainly hyperactive: the pancreatic $\beta$-cells and the corticoadrenal cells. Such hyperactivity increases the circulating levels of both insulin and GC, which in due time will perpetuate and aggravate the adipogenic process; these changes lead to a hypertrophic expansion of WAT mass characterized by exacerbated proinflammatory adipokine production and enhanced oxidative stress. INS, insulin; LEP, leptin; GC, glucocorticoid; AC, adrenal cortex; $\mathrm{ACTH}$, adrenocorticotropic hormone; AP, anterior pituitary. The question mark is included because the ACTH inhibitory effect on WAT LEP production has been addressed in 3T3-L1 adipocytes only; see Norman et al. [155].

In fact, the above-mentioned administration of an FRD for 8-weeks induces an increase in mRNA expression levels of PPAR $\gamma-2$ and Zfp423, indicating that high APC competency is maintained during this period. This phenomenon might be responsible for the small new adipocyte population observed in these rats, as discussed before. Because FRD intake did not modify APC expression of 2 antiadipogenic factors Pref- 1 and Wnt10b, its effect could be mainly ascribed to changes in APC competency.

Altogether, these results demonstrate that long-term FRD intake altered the RPAT APC by enhancing their adipogenic potential. The fact that this fructose-induced enhancing effect can be reproduced in vitro and is blunt- ed by its replacement by glucose in the culture medium strongly suggests that fructose directly and specifically modulates the adipogenic competency [33]. This effect was also demonstrated in rats born from mothers fed with an FRD during pregnancy. At 60 days of age, these rats portray impaired glucose tolerance and high circulating levels of LEP, while their RPAT mass shows an enhanced LEP gene expression and the presence of hypertrophic adipocytes that oversecrete LEP in vitro [38].

Chronic circadian desynchronization induced by repeated changes in the 12-h light-dark cycle twice a week, increases food intake, body weight, and RPAT mass in male F344 rats. Proteomic studies demonstrated that this circadian alteration induces an upregulation of 2-DE protein spots of proteins involved in carbohydrate metabolism and in the citric acid cycle, thus suggesting a positive energy balance status [39]. The simultaneous upregulation of hypothalamic $\gamma$-amino butyric acid (GABA) aminotransferase present in these animals, suggests a link between the brain GABA-ergic system and the food intake modulation; furthermore, the upregulation of different metabolic parameters (fatty acid-binding protein 4) and downregulation of $78-\mathrm{kDa}$ glucose-regulated protein in WAT, implies the development of IR. These findings partially reproduced the changes induced by genotype and a high-fat diet, reinforcing the concept that circadian rhythm alteration plays an important role in obesity development and associated homeostatic dysfunction.

\section{Potential Effect of Intervention upon WAP Cells on \\ Obesity Development}

Daquinag et al. [40] have shown that targeted WAP cytoablation results in a long-term WAT growth suppression, despite increased caloric intake in a mouse model of dietary-induced obesity. They also showed that WAP depletion results in a compensatory population of beige adipocytes. Consistent with the reported thermogenic capacity of the later tissue, WAP-depleted mice display increased energy expenditure. Thus, targeting white adipocyte progenitors could render an effective strategy to sustained modulation of WAT metabolic activity [40].

\section{Circadian Modulation of Energy Metabolism}

The Circadian Clock: Its Molecular Mechanism, Its Components, and Its Role in the Development of Metabolic Dysfunctions

There is clear evidence that energy metabolism is modulated by the circadian clock at both central and local 


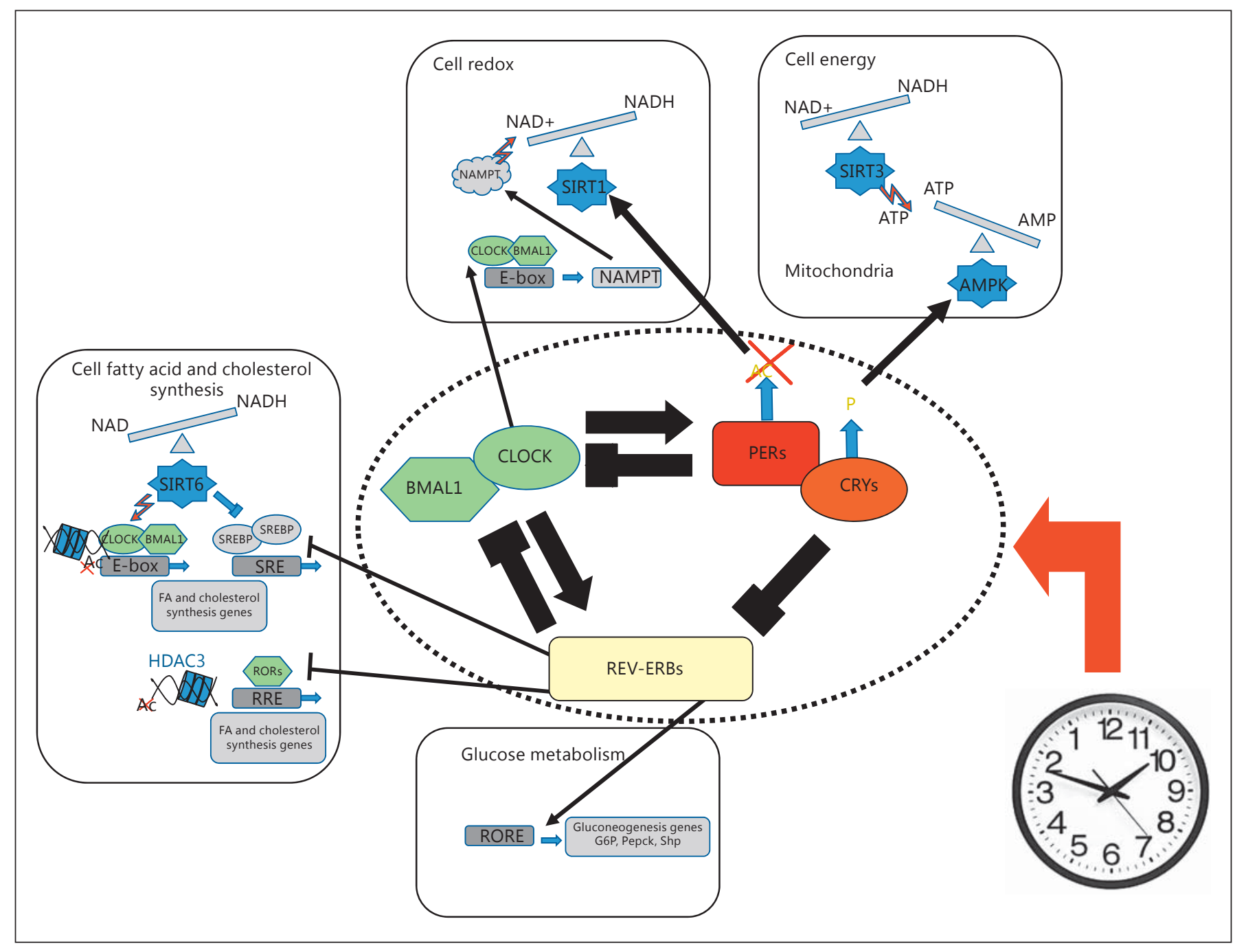

Fig. 5. A master regulatory role of the circadian clock in the metabolic pathways. Circadian clock proteins (CLOCK, BMAL, PERs, CRYs, REV-ERBs) regulate metabolism by interacting with cell energy and redox balance through different mechanisms such as sensing specific metabolites (e.g., NAD, NADP, ATP) and inter- acting with specific genes in a wide range of metabolic areas: lipid and carbohydrate homeostasis. These mechanisms are both direct and chromatin-mediated, with important interventions of proteins like SIRT (belonging to the deacetylase family). levels. The central pacemaker or circadian clock prepares individuals for predictable events such as turning from day to night, and thereby synchronizing physiological functions to particular daytime periods in order to optimize metabolic efficiency. Other factors contribute to the synchronizing process such as light-dark cycle, food intake, exercise, and sleep. On account of the existence of their synchronized activity, we can envisage the potential use of a "chronotherapeutic approach for obesity," which we will discuss later in this review.

The central pacemaker is located at the hypothalamic suprachiasmatic nucleus ( $\mathrm{SCN}$ ), though the mammalian circadian system also comprises peripheral oscillators located in almost every cell of the body [41, 42]. This multiple individual tissue-specific cellular clock system is based on a small number of core clock genes interlocked by transcriptional and posttranslational feedback loops [41]. The positive drive for the daily clock is constituted by 2 transcription factors encoded by Bmall and Clock genes. They form heterodimeric complexes that control the transcription of other clock genes named Period (Per1/Per2/Per3) and Cryptochrome (Cry1/Cry2), which in turn provide the negative feedback signal that shuts down the positive drive (Fig. 5). Any alteration in this ac- 
curate mechanism initiates misalignment with multiple metabolic effects.

To support this concept, we will analyze evidence on how metabolism, particularly glucose homeostasis and adipogenesis, is affected when clock members are mutated or even absent due to knockout (KO) technology. The concept that disruption of circadian rhythms enhances the risk of metabolic diseases such as obesity, type 2 diabetes mellitus (T2DM), and the metabolic syndrome arises from the observation of clock member $\mathrm{KO}$ genes in mice. Administration of a hypercaloric diet to Clock mutant mice resulted in accumulation of energy and body mass to values double than those recorded in control animals [43]. These mice also have hyperglycemia, hypoinsulinemia [42], hyperphagia, obesity, impaired gluconeogenesis, and lipid homeostasis [43, 44]. Mice with Per3 $\mathrm{KO}$ alter their body mass and composition and accumulate fat by enhancing adipogenesis $[45,46]$. Moreover, Bmal1 KO mice have impaired glucose and lipid homeostasis [47] as well as lack of rhythmicity in insulin action and activity patterns that can be restored by the paralogous gene Bmal2. Interestingly, Per3 KO also show impaired lipid metabolism and obesity when fed a high-fat diet [48]. Conversely, constant expression of Per3 inhibited adipogenesis in MSCs [45]. Otherwise, Per2 blocks recruitment of PPAR $\gamma$ to target promoters in genes involved in the control of adipogenesis and insulin sensitivity, while its absence results in enhanced adipocyte differentiation [49]. Furthermore, overall body glucose regulation during the day is organized by the liver peripheral molecular clock [48, 49]. Altogether, this evidence demonstrates that circadian disruption leads to IR and obesity, thus lending additional support to the crucial roles played by circadian clock genes in both adipogenesis as well as glucose and lipid homeostasis, particularly in adipose tissue [50]. The fact that half of the nuclear receptors identified in the liver and adipocytes exhibit a $24-\mathrm{h}$ periodicity lends further support to this assumption [51, 52].

Circadian regulatory mechanisms utilize both neural and humoral communication to tightly control insulin, LEP, and glucose peripheral levels [53], and rats with hampered CNS function showed abnormalities in glucose metabolism and insulin effect [54-56]. Similarly, Clock mutant mice showed impaired glucose utilization and appetite control [42, 43, 47]. At the clinical level, several studies have also shown that CLOCK variants correlate with BMI [57], weight loss, sleep duration and total plasma cholesterol concentration in obese Caucasian people [58]. CLOCK and CRY1 polymorphisms might be involved in individual susceptibility to abdominal obesity in the Chinese Han population [59]. Variants of the circadian clock-related gene Mntr1b, which encodes pineal hormone melatonin receptor $1 \mathrm{~B}$, portrait impaired glucose-induced insulin secretion, abnormal fasting glycemia and a higher risk of developing T2DM [60-65] thus conditioning, at least in part, melatonin actions. Additionally, melatonin synthesis and release undergo strong daily oscillations regulated by the master circadian clock in the CNS and by light.

Single nucleotide polymorphisms (SNPs) in the brainmuscle-ARNT-like protein-2 (BMAL2) gene have also been associated with high risk of developing T2DM in obese patients [66]. Cross-sectional studies have reported associations between the CLOCK locus and prevalence of obesity, plasma glucose levels, hypertension, and T2DM. Recently, further associations with cardiovascular disease (CVD) have been found (association between a CLOCK polymorphism and stroke in T2DM), suggesting that core clock genes may significantly contribute to increased CVD risk in T2DM [67]. All these genome-wide association studies in human population support experimental evidence for a genetic link between the circadian clock, overall metabolism, and susceptibility to metabolic disease, particularly obesity.

\section{Circadian Clock Dysfunction and Obesity}

Apparently, synchronization of many different metabolic pathways, through gene expression and their downstream activation with feeding time, may represent an adaptive evolution to improve and optimize energy balance. Thus, we will briefly review reported evidence of glucose homeostasis regulation by circadian clocks and how disruption of circadian rhythms drives to pathological states such as obesity, metabolic syndrome, and T2DM $[55,56]$.

The correlation between increased occurrence of obesity and the ubiquity of modern social habits, such as light at night (LAN), unusual meal timing, irregular sleep/ wake schedules and traveling between different time zones, all encompassed by a $24 \mathrm{~h} / 7$ days lifestyle, strongly suggests that impairment of the circadian system is involved in the etiology of several illnesses. It has been reported that even slight changes in LAN alter meal timing and body mass accumulation in mice $[68,69]$. Several clinical surveys have also shown increased prevalence of obesity in night-shift workers, showing that artificial lighting may contribute to increased prevalence of metabolic disorders [70,71]. Altogether, this evidence suggests that inappropriate time administration of food may dis- 
rupt the normal metabolic profile, leading to a desynchronized state causally linked to obesity development. In this regard, medical students portraying nocturnal life habits showed decreased plasma melatonin and LEP peaks. However, plasma glucose concentration remained high during the night while insulin secretion decreased markedly, thus indicating that nocturnal life impairs insulin response to glucose, likely becoming one of the risk factors associated with modern social habits [72]. Circadian misalignment also alters circulating LEP levels, an effect that may negatively affect appetite and energy balance [73-75]. The increased obesity rate recorded in 100,000 women of the Breakthrough Generations Study, associated with increased levels of LAN exposure, supports this assumption [70]. Moreover, data from nurses and midwives showed that they had a higher risk of developing obesity [71]. Thus, both animal models and human data have clearly proved that circadian disruption leads to IR and obesity [50].

On the other hand, genetic modifications causing obesity and diabetes lead to circadian disruption. Genetically obese and diabetic $\mathrm{db} / \mathrm{db}$ mice, lacking $\mathrm{Ob}-\mathrm{Rb}$, are arrhythmic regarding feeding and general activity; they present an extended endogenous period and altered photic integration [76]. The same group has demonstrated that LEP modulates daily blood glucose rhythmicity by modulating food intake [77, 78]. Additionally, rats submitted to forced activity during the sleeping phase, showed altered temporal pattern of food intake, loss of glucose rhythmicity and a reversed rhythm of triacylglycerol levels, though CNS activity was intact. Similarly, in night workers the combination of altered work and eating activities, may lead to internal desynchronization by uncoupling metabolic functions from the biological clock which remained fixed to the LD cycle $[74,75,79,80]$. Furthermore, feeding mice at the wrong time (inactive or sleeping phase), desynchronizes peripheral clocks and causes obesity by inducing hyperphagia, physical inactivity, LEP resistance, hepatic lipid accumulation, and hyperadiposity. Liver and skeletal muscle metabolic rhythms become uncoupled as shown by temporal expression of desynchronized circadian clock genes in the skeletal muscle [81].

It has also been shown that an abnormal metabolic response such as obesity, to a given nutritional challenge, depends on the combination of several genes' action rather than on a single one, and even to a precise localization at a tissue level of such combination. Bmall $\mathrm{KO}$ mice show different metabolic impairment depending on the tissue affected. Deletion of this allele in adipose tissue $(\mathrm{ABKO})$, as well as its combined deletion in liver and ad- ipose tissue (LABKO), alters feeding behavior and locomotive activity. However, animals with the combination of liver and adipose deletion only develop obesity after exposure to a diabetogenic diet [82]. Deletion of Bmal1 in adult murine $\beta$-cells resulted in impaired metabolic adaptation to high fat diet: they display fasting and diurnal hyperglycemia, impaired glucose tolerance, loss of glucose-stimulated insulin secretion and lack of $\beta$-cell expansion. This observation points to $\beta$-cell circadian clock as a novel regulator of compensatory $\beta$-cell expansion in response to an increased insulin demand, induced by administration of an obesogenic diet. Because obesity and IR are risk factors for developing T2DM and even when not every individual exposed to a cafeteria diet will become diabetic, it is important to identify key factors involved in a proper response to defiant lifestyles [83].

At the clinical level, in a recent survey, samples of subcutaneous adipose tissue from 50 overweight subjects were collected before and after 8 weeks of administration of a hypocaloric diet ( $800 \mathrm{kcal} /$ day plus $200 \mathrm{~g}$ vegetables/ day). The expression of core clock genes (assayed by quantitative real time PCR), Per2 and NR1D1, was increased after the weight loss, and their levels correlated with this decrease and the expression of several genes involved in fat metabolism (FASN, LPL, PPARG, PGC1A, ADIPOQ), energy metabolism (SIRT1), and inflammation. Thus, clock gene expression in human subcutaneous adipose tissue is regulated by body weight changes and associated with BMI, serum cholesterol levels and the expression of metabolic and inflammatory pathways involved in adapting adipose tissue metabolism to changes in energy intake [84].

Because the circadian pattern of adipokines is blunted in obese subjects, another study tested the possibility that bariatric surgery could restore it. Surgical intervention rapidly decreased 24-h LEP levels but, after 3 months, it did not recover the physiological nocturnal rise of LEP levels present in lean subjects [85]. On the other hand, stimulated lipolysis by activated natriuretic peptide receptors undergoes circadian regulation [86], as well as adiponectin expression through the circadian expression of its transcription factor PPAR $\gamma$ and its coactivator PGC1 $\alpha$ [87].

\section{Circadian Regulation of Epigenetic Changes in Obesity} and Other Metabolic Diseases

A link between epigenetic changes (DNA acetylation/ methylation) of the circadian clock system and metabolism has already been described. In this regard, it has been shown that the molecular clock regulates the rhythm 
of NAD (nicotinamide adenine dinucleotide 1), an important cofactor of the histone deacetylase sirtuin (silent mating type information regulation 2 homolog) 1 (SIRT1). In this way, the clock controls SIRT1 effects on other genes: through protein acetylation/deacetylation and chromatin modification, it regulates oscillating expression of metabolic genes. Particularly in hepatocytes, the Rev-erba rhythm orchestrates the binding of histone deacetylase 3 (HDAC3), causing chromatin modification that coordinates the expression of lipid metabolic pattern. Rhythmicity disruption of DNA binding and HDAC3 deacetylation leads to liver steatosis [88-93]. Further association between the methylation status of clock genes (CLOCK, Bmal1, and Per2) with obesity, metabolic syndrome, and weight loss has been also reported. Interestingly, this methylation status could be used as a biomarker to predict weight loss success [94].

A recent study has demonstrated that a weight loss intervention based on an energy-controlled Mediterranean diet, may influence the methylation levels of 3 clock genes, Bmal1, CLOCK, and NR1D1, being an association between the methylation levels and the diet-induced serum lipid profile (total cholesterol and low-density lipoprotein cholesterol). Further, significant and positive correlations were found between changes in the methylation levels in the CpG 5-9 region of Bmal1 due to the intervention and changes in serum lipids [95].

\section{Circadian Regulation of OS, Energy State, and \\ Metabolic Functions}

We have already mentioned that the extra adipose tissue found in the obesity condition provides excess of adipokines that increase both inflammation and oxidative damage of proteins and lipids. We have to stress that most enzymes responsible for the antioxidant defense are under circadian control, and when their expression pattern is impaired by a high-fat diet (HFD), this effect may be prevented by melatonin administration [96]. This control includes the regulatory role of redox coenzymes $(\mathrm{NAD}(\mathrm{P})+/ \mathrm{NAD}(\mathrm{P}) \mathrm{H}, \mathrm{GSH} / \mathrm{GSSG})$, reactive oxygen species (superoxide anion, hydrogen peroxide), and antioxidants (melatonin) [97].

\section{Sleep and Obesity}

Traditional lifestyle factors such as unbalanced diet and physical inactivity are not the only players involved in the dramatic rise in the incidence and prevalence of T2DM. In this regard, Arora and Taheri [98] have reviewed the evidence supporting sleep as a new important lifestyle abnormal behavior.
In a recent study, performed with 593 patients with a recent diagnosis of T2DM, sleep debt resulted in longterm metabolic disruption, which may promote the progression of the disease. This was concluded after examination of obesity status (by BMI), central adiposity (by waist circumference), and IR (fasting blood samples) and sleep debt assessed by 7-day sleep diaries (average weekend sleep duration minus average weekday sleep duration). The examination of cross-sectional and prospective associations between sleep debt and adiposity measures, as well as HOMA-IR in T2DM at baseline, 6 months, and 12 months after lifestyle intervention, showed marked changes: for every 30 min of weekday sleep debt, the risk of obesity and IR at 12 months increased by 18 and $41 \%$, respectively. At baseline, these people compared to those without weekday sleep debt, were $72 \%$ more likely to become obese, while 6 months later, the sleep debt was significantly associated with obesity and IR after adjustment $(\mathrm{OR}=1.90$ and 2.07, respectively). A further increase was observed at 12 months of sleep debt with OR of 2.10 and 3.16 , for obesity and IR, respectively [99].

It has also been described that sleep quality rather than sleep duration plays an important role in IR in these newly diagnosed T2DM patients. Because the average number of night awakenings was positively correlated with BMI and negatively associated with logged HOMA2-IR [100], BMI may mediate the relationship between indicators of sleep quality and IR. These findings indicate the need for improving sleep quality to prevent the development of obesity and IR as well as its progression to T2DM. The association between the genetic variants of the clock gene, obesity, and sleep duration has helped to identify at risk CLOCK genotypes, a fact that may help to identify individuals who are more susceptible to overeating and gaining weight when experiencing sleep deprivation [101].

\section{Chrononutrition}

This term refers to a new field linking nutrition and circadian regulation. It refers not only to the food as a modulator of circadian clocks but also to the time at which those meals are eaten. As previously mentioned, feeding time sets the phase of peripheral circadian clocks. Time-restricted feeding for only a week impairs the phase of the clock and clock-controlled gene rhythmic expression in peripheral tissues, uncoupling them from the central pacemaker in the SCN [102]. The liver can easily adapt to a new feeding time in about 3 days, and the balance between food intake and starvation periods sets the phase. Eating at night shortens the starvation period 
causing phase alterations in peripheral clocks $[103,104]$. A well-balanced diet may induce a rapid phase shift in the liver clock: a combination of carbohydrate and protein is effective, while protein, sugar, or oil is not $[103,105]$. An intraperitoneal injection of glucose combined with amino acids can reset the liver clock by modulating the expression levels of clock core genes [106]. Therefore, nutrients containing glucose and amino acids can induce rapid changes in the expression of clock genes, especially Per2 and Rev-erba. Other common diet components such as caffeine [107], salt [108], and resveratrol [109], may alter circadian rhythms at the molecular level. Finally, the effects of a high-fat diet on the circadian system are very important for the general population, and also researchers, because globalization has spread out western or cafeteria diet worldwide. In fact, feeding mice with a high-fat diet disrupts feeding behavior and molecular circadian rhythms in the liver and adipose tissue, indicating that this diet also affects the central clock [110-113]. However, feeding mice with HFD in a time-restricted fashion prevents obesity even without reducing caloric content $[69,114]$. This may indicate a restoring effect over phase amplitude of clocks. Additionally, mice gained more weight when fed with a normal or a high-fat diet during resting time (day), than during activity period (night). Similar results were obtained feeding rats with a butter based high-fat diet during the light phase [115], resembling the night eating syndrome in humans. Further, several human studies have demonstrated that to prevent obesity and its undesirable consequences, it is advisable to make bigger breakfasts and smaller dinners and also early mealtimes in general [116].

\section{Obesity Prevention and Treatment}

\section{Traditional Approach}

Because obesity represents a heavy burden for the health budget, the community and, the general population, the big challenge is to increase awareness, resources, and tools to identify pathogenic factors and design comprehensive and individualized treatment strategies [117, 118]. Consequently, current recommendations for obesity management provide a general framework for appropriate, safe, and effective implementation of available treatment options [119-121] (Fig. 6). Across the recommendations, comprehensive lifestyle management, including meal planning, exercise, and behavioral intervention, is the cornerstone of all weight loss treatment appropriate for all obese people. The success of this approach depends on 3 key components: reduced calorie intake, increased physical activity, and behavioral intervention. However, despite their best attempts, many people cannot achieve successful long-term weight loss, even with extremely effective lifestyle intervention programs such as those used in the DPP and Look AHEAD trials [122]. Pharmacotherapy is an appropriate option for people with $\mathrm{BMI} \geq 27$ and complications or with $\mathrm{BMI} \geq 30$, a recommendation consistent with label indications for approved agents [123]. Regardless, drug therapy and more intensive interventions may be associated with lifestyle management. In general, any pharmacotherapy approved for long-term obesity management produced an average weight loss of $5-15 \%$ over 1 year when associated with intensive, comprehensive lifestyle intervention. Their use, however, has been associated with some adverse effects which have added specific warnings and precautions regarding their safe and effective use $[117,123]$. Therefore, these therapies might be reserved for people at greater health risk due to obesity-associated complications and for those who failed to achieve weight loss despite tight adherence to diet and physical activity. Although a comprehensive discussion on bariatric surgery is beyond the scope of our review, we need to mention that it might become an appropriate treatment option for some patients. Commonly used bariatric procedures include gastric banding, Roux-en-Y gastric bypass, and sleeve gastrectomy [124-128]. On average, weight loss with bariatric surgery is greater than with nonsurgical interventions, around $15-35 \%$ depending on the procedure $[120,129-$ 132]. Although bariatric surgery may result in greater weight loss than other obesity interventions, it is an invasive procedure that requires important long-term commitment and follow-up by patients and health-care teams. Consequently, current treatment recommendations reserve bariatric surgery for people with BMI $\geq 40$ or $\geq 35$ with obesity-associated complications $[120,126-128$, 133-135]. Those who are interested in further updating their knowledge on current alternatives for obesity treatment will find a recent review to be a great help $[121,136]$.

\section{A Chronobiological Approach to Obesity Treatment}

As mentioned before, environmental factors or stressors of the so-called contemporary " $24 / 7$ " societies have pronounced effects on metabolism producing circadian clock disruption [137-139]. Furthermore, people whose work involves irregular time schedules and forced exposure to bright LAN (night/shift workers) show significant disruptions in sleep architecture, and increased prevalence of obesity. These lines of evidence indicate that the 


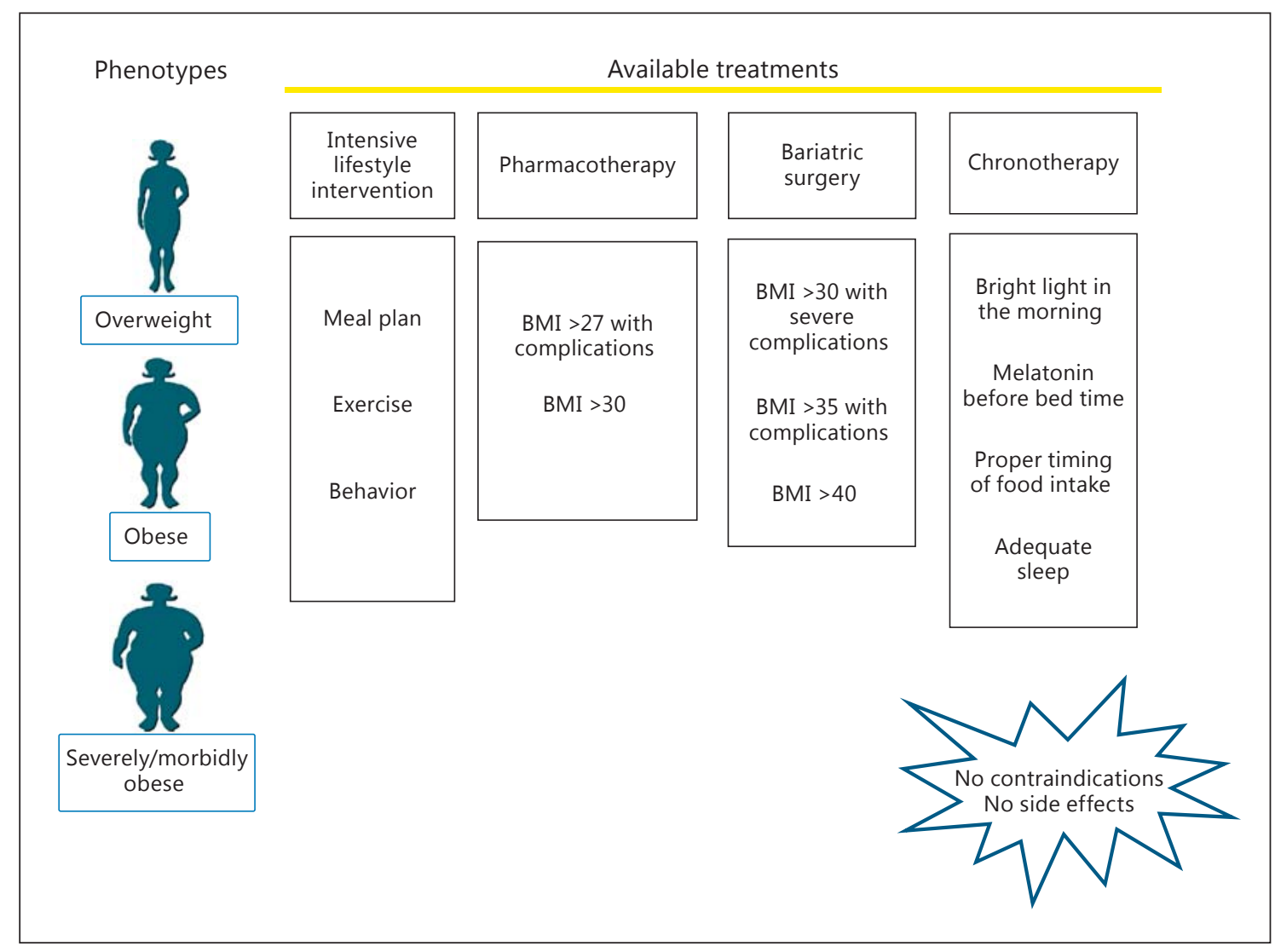

Fig. 6. Algorithm for available interventions for different obese phenotypes. Traditional approaches to lose weight and its prescription sequence (including bariatric surgery) are represented in the first 3 columns of the figure. They also include specific indica- tions. On the other hand, chronotherapeutic strategy (last column) and its components offer a new approach with potential great success rate and few side effects. BMI, body mass index. system fails to adjust properly to environmental and/or stressor changes disrupting overall metabolic homeostasis. In time, this disruption could contribute to the increasing worldwide prevalence of obesity/T2DM. Thus, and from the point of view of public health, it might be important to implement active awareness campaigns on the importance of appropriate timing for food intake, daytime activity, exposure to sunlight and proper sleep. In this context, melatonin is an interesting chronotherapeutic option (Fig. 6) which can reset the phase and amplitude of circadian rhythms [140-142]. Animal models of obesity showed that melatonin also possesses cytoprotective properties which may prevent undesirable effects $[143,144]$ such as inflammation process and others [96, 145]. On the other hand, several controlled trials have shown that melatonin administration is useful for treating metabolic and cardiovascular comorbidities [146150]. As already mentioned, at an early stage, nonphar- macological approaches are highly recommended, while drug treatment may be used in patients refractory to those approaches. Melatonin has limited toxicity effects and a stronger safety profile than many other pharmaceutical agents [151]. In fact, very high melatonin doses (300 mg/ day) were administered safely and well tolerated for up to 2 years in patients with lateral amyotrophic sclerosis [152]. Consequently, melatonin administration in combination with strategically timely administration of light therapy and appropriate food intake appears to be justified for normalizing melatonin amplitude and synchronizing endogenous circadian rhythms in obesity. Its administration time is critical though: by strengthening of circadian clock function with bright light in the morning and melatonin before bed time, plus tight control of glucose/lipid homeostasis with proper timing of food intake (peripheral clock entraining); this combined regime would provide an ideal treatment for restoration of im- 
paired circadian rhythms, representing a cutting-edge nonpharmaceutical chronotherapeutic strategy for the treatment of obese patients.

\section{Conclusions and Remarks}

A neuroendocrine, metabolic, and circadian view of obesity can help to understand the multiple and complex mechanisms involved in its development and maintenance, as well as to provide new effective approaches for its control and treatment. In this regard, chronotherapy may be a promising approach. Although it is still difficult to precisely identify the initial impaired mechanism that triggers the development of the obese phenotype, it is clear that once established, it greatly contributes to its perpetuation. Until we can identify this mechanism, the awareness of the population regarding the importance of appropriate timing for food intake, daytime activity, exposure to sunlight, and proper sleep time period represents an effective obesity prevention strategy.

\section{Acknowledgements}

Authors wish to thank Mrs. Susan H. Rogers and Ms. Rebecca Doyle for their careful English (grammar and style) correction of the manuscript. This research was supported by a grant from Fondation pour la Recherche en Endocrinologie, Diabetologie et Metabolisme (FPREDM 052015 to E.S.). E.S.P., E.S. and J.J.G. are members of the Research Career from CONICET (Argentina).

\section{Disclosure Statement}

All authors declare no conflict of interest.

\section{References}

1 World Health Organization: Obesity and Overweight. Fact Sheet No 311, January 2015. Geneva, World Health Organization, 2015 http://www.who.int/mediacentre/factsheets/ fs311/en/ (accessed Nov 1, 2015).

2 Arena R, Guazzi M, Lianov L, Whitsel L, Berra K, Lavie CJ, Kaminsky L, Williams M, Hivert MF, Cherie Franklin N, Myers J, Dengel D, Lloyd-Jones DM, Pinto FJ, Cosentino F, Halle M, Gielen S, Dendale P, Niebauer J, Pelliccia A, Giannuzzi P, Corra U, Piepoli MF, Guthrie G, Shurney D; AHA Writing Group, Arena R, Berra K, Dengel D, Franklin NC, Hivert MF, Kaminsky L, Lavie CJ, Lloyd-Jones DM, Myers J, Whitsel L, Williams M; ESC/ EACPR Writing Group, Corra U, Cosentino F, Dendale P, Giannuzzi P, Gielen S, Guazzi M, Halle M, Niebauer J, Pelliccia A, Piepoli MF, Pinto FJ; ACPM Writing Group, Guthrie G, Lianov L, Shurney D: Healthy lifestyle interventions to combat noncommunicable disease - a novel nonhierarchical connectivity model for key stakeholders: a policy statement from the American Heart Association, European Society of Cardiology, European Association for Cardiovascular Prevention and Rehabilitation, and American College of Preventive Medicine. Eur Heart J 2015;36:20972109.

3 Bosello O, Donataccio MP, Cuzzolaro M: Obesity or obesities? Controversies on the association between body mass index and premature mortality. Eat Weight Disord 2016;21: 165-174.

4 Sun K, Kusminski CM, Scherer PE: Adipose tissue remodeling and obesity. J Clin Invest 2011;121:2094-2101.
5 Kalra SP, Dube MG, Pu S, Xu B, Horvath TL, Kalra PS: Interacting appetite-regulating pathways in the hypothalamic regulation of body weight. Endocr Rev 1999;20:68-100.

6 Dibner C, Schibler U, Albrecht U: The mammalian circadian timing system: organization and coordination of central and peripheral clocks. Annu Rev Physiol 2010;72:517-549.

7 Ronti T, Lupattelli G, Mannarino E: The endocrine function of adipose tissue: an update. Clin Endocrinol (Oxf) 2006;64:355-365.

8 Kras KM, Hausman DB, Hausman GJ, Martin RJ: Adipocyte development is dependent upon stem cell recruitment and proliferation of preadipocytes. Obes Res 1999;7:447-491.

9 Gimble JM, Katz AJ, Bunnell BA: Adiposederived stem cells for regenerative medicine. Circ Res 2007;100:1249-1260.

10 Bianco P, Robey PG, Simmons PJ: Mesenchymal stem cells: revisiting history, concepts, and assays. Cell Stem Cell 2008;2:313-319.

11 Caplan AI, Correa D: The MSC: an injury drugstore. Cell Stem Cell 2011;9:11-15.

12 Kolonin MG, Simmons PJ: Combinatorial stem cell mobilization. Nat Biotechnol 2009; 27:252-253.

13 Daquinag AC, Zhang Y, Kolonin MG: Vascular targeting of adipose tissue as an anti-obesity approach. Trends Pharmacol Sci 2011;32: 300-307.

14 Traktuev D, Merfeld-Clauss S, Li J, Kolonin M, Arap W, Pasqualini R, Johnstone BH, March KL: A population of multipotent CD34-positive adipose stromal cells share pericyte and mesenchymal surface markers, reside in a periendothelial location, and stabilize endothelial networks. Circ Res 2008;102:77-85.
15 Rodeheffer MS, Birsoy K, Friedman JM: Identification of white adipocyte progenitor cells in vivo. Cell 2008;135:240-249.

16 Tang W, Zeve D, Suh JM, Bosnakovski D, Kyba M, Hammer RE, et al: White fat progenitor cells reside in the adipose vasculature. Science 2008;322:583-586.

17 Planat-Benard V, Silvestre JS, Cousin B, André M, Nibbelink M, Tamarat $R$, Clergue $M$, Manneville C, Saillan-Barreau C, Duriez M, Tedgui A, Levy B, Pénicaud L, Casteilla L: Plasticity of human adipose lineage cells toward endothelial cells: physiological and therapeutic perspectives. Circulation 2004;109:656-663.

18 Mitchell JB, McIntosh K, Zvonic S, Garrett S, Floyd ZE, Kloster A, Di Halvorsen Y, Storms RW, Goh B, Kilroy G, Wu X, Gimble JM: Immunophenotype of human adipose-derived cells: temporal changes in stromal-associated and stem cell-associated markers. Stem Cells 2006;24:376-385.

19 Giovambattista A, Gaillard RC, Spinedi E: Ghrelin gene-related peptides modulate rat white adiposity. Vitam Horm 2008;77:171-205.

20 Castrogiovanni D, Gaillard RC, Giovambattista A, Spinedi E: Neuroendocrine, metabolic, and immune functions during the acute phase response of inflammatory stress in monosodium L-glutamate-damaged, hyperadipose male rat. Neuroendocrinology 2008; 88:227-234.

21 Zubiría MG, Vidal-Bravo J, Spinedi E, Giovambattista A: Relationship between impaired adipogenesis of retroperitoneal adipose tissue and hypertrophic obesity: role of endogenous glucocorticoid excess. J Cell Mol Med 2014;18:1549-1561. 
22 Alzamendi A, Giovambattista A, Raschia A, Madrid V, Gaillard RC, Rebolledo O, Gagliardino JJ, Spinedi E: Fructose-rich diet-induced abdominal adipose tissue endocrine dysfunction in normal male rats. Endocrine 2009;35:227-232.

23 Campos CF, Duarte MS, Guimarães SE, Verardo LL, Wei S, Du M, Jiang Z, Bergen WG, Hausman GJ, Fernyhough-Culver M, Albrecht E, Dodson MV: Review: animal model and the current understanding of molecule dynamics of adipogenesis. Animal 2016;8:1-6.

24 Walder K, Filippis A, Clark S, Zimmet P, Collier GR: Leptin inhibits insulin binding in isolated rat adipocytes. J Endocrinol 1997; 155:R5-R7.

25 Morioka T, Asilmaz E, Hu J, Dishinger JF, Kurpad AJ, Elias CF, Li H, Elmquist JK, Kennedy RT, Kulkarni RN: Disruption of leptin receptor expression in the pancreas directly affects beta cell growth and function in mice. J Clin Invest 2007;117:2860-2868.

26 Covey SD, Wideman RD, McDonald C, Unniappan S, Huynh F, Asadi A, Speck M, Webber T, Chua SC, Kieffer TJ: The pancreatic beta cell is a key site for mediating the effects of leptin on glucose homeostasis. Cell Metab 2006;4:291-302.

27 Navarra P, Tsagarakis S, Faria MS, Rees LH, Besser GM, Grossman AB: Interleukins- 1 and -6 stimulate the release of corticotropin-releasing hormone- 41 from rat hypothalamus in vitro via the eicosanoid cyclooxygenase pathway. Endocrinology 1991;128:37-44.

28 Spinedi E, Hadid R, Daneva T, Gaillard RC: Cytokines stimulate the CRH but not the vasopressin neuronal system: evidence for a median eminence site of interleukin-6 action. Neuroendocrinology 1992;56:46-53.

29 Cherradi N, Capponi AM, Gaillard RC, Pralong FP: Decreased expression of steroidogenic acute regulatory protein: a novel mechanism participating in the leptin-induced inhibition of glucocorticoid biosynthesis. Endocrinology 2001;142:3302-3308.

30 Yokosuka M, Xu B, Pu S, Kalra PS, Kalra SP: Neural substrates for leptin and neuropeptide Y (NPY) interaction: hypothalamic sites associated with inhibition of NPY-induced food intake. Physiol Behav 1998;64:331-338.

31 Zubiría MG, Fariña JP, Moreno G, Gagliardino JJ, Spinedi E, Giovambattista A: Excess fructose intake-induced hypertrophic visceral adipose tissue results from unbalanced precursor cell adipogenic signals. FEBS J 2013; 280:5864-5874.

32 Alzamendi A, Giovambattista A, García ME, Rebolledo OR, Gagliardino JJ, Spinedi E: Effect of pioglitazone on the fructose-induced abdominal adipose tissue dysfunction. PPAR Res 2012;2012:259093.

33 Zubiría MG, Alzamendi A, Moreno G, Rey MA, Spinedi E, Giovambattista A: Long-term fructose intake increases adipogenic potential: evidence of direct effects of fructose on adipocyte precursor cells. Nutrients 2016;8: E198.
34 Cristancho AG; Lazar MA: Forming functional fat: a growing understanding of adipocyte differentiation. Nat Rev Mol Cell Biol 2011;12:722-734.

35 Sengenès C, Lolmède K, Zakaroff-Girard A, Busse R, Bouloumié A: Preadipocytes in the human subcutaneous adipose tissue display distinct features from the adult mesenchymal and hematopoietic stem cells. J Cell Physiol 2005;205:114-122.

36 Gupta RK, Arany Z, Seale P, Mepani RJ, Ye L, Conroe HM, Roby YA, Kulaga H, Reed RR, Spiegelman BM: Transcriptional control of preadipocyte determination by Zfp423. Nature 2010;464:619-623.

37 Tontonoz P, Spiegelman BM: Fat and beyond: the diverse biology of PPARgamma. Annu Rev Biochem 2008;77:289-312.

38 Alzamendi A, Zubiría G, Moreno G, Portales A, Spinedi E, Giovambattista A: High risk of metabolic and adipose tissue dysfunctions in adult male progeny, due to prenatal and adulthood malnutrition induced by fructose rich diet. Nutrients 2016;8:E178.

39 Mishra A, Cheng CH, Lee WC, Tsai LL: Proteomic changes in the hypothalamus and retroperitoneal fat from male F344 rats subjected to repeated light-dark shifts. Proteomics 2009;9:4017-4028.

40 Daquinag AC, Tseng C, Salameh A, Zhang Y, Amaya-Manzanares F, Dadbin A, Florez F, Xu Y, Tong Q, Kolonin MG: Depletion of white adipocyte progenitors induces beige adipocyte differentiation and suppresses obesity development. Cell Death Differ 2015;22:351-363.

41 Dibner C, Schibler U, Albrecht U: The mammalian circadian timing system: organization and coordination of central and peripheral clocks. Annu Rev Physiol 2010;72:517-549.

42 Marcheva B, Ramsey KM, Buhr ED, Kobayashi $\mathrm{Y}$, Su $\mathrm{H}$, Ko CH, Ivanova $\mathrm{G}$, Omura $\mathrm{C}$, Mo S, Vitaterna MH, Lopez JP, Philipson LH, Bradfield CA, Crosby SD, JeBailey L, Wang X, Takahashi JS, Bass J: Disruption of the clock components CLOCK and BMAL1 leads to hypoinsulinaemia and diabetes. Nature 2010; 466:627-631.

43 Turek FW, Joshu C, Kohsaka A, Lin E, Ivanova G, McDearmon E, Laposky A, LoseeOlson S, Easton A, Jensen DR, Eckel RH, Takahashi JS, Bass J: Obesity and metabolic syndrome in circadian Clock mutant mice. Science 2005;308:1043-1045.

44 Oishi K, Atsumi G, Sugiyama S, Kodomari I, Kasamatsu M, Machida K, Ishida N: Disrupted fat absorption attenuates obesity induced by a high-fat diet in Clock mutant mice. FEBS Lett 2006;580:127-130.

45 Costa MJ, So AY, Kaasik K, Krueger KC, Pillsbury ML, Fu YH, Ptacek LJ, Yamamoto KR, Feldman BJ: Circadian rhythm gene period 3 is an inhibitor of the adipocyte cell fate. J Biol Chem 2011;286:9063-9070.

46 Dallmann R, Weaver DR: Altered body mass regulation in male mPeriod mutant mice on high-fat diet. Chronobiol Int 2010;27:13171328.
47 Rudic RD, McNamara P, Curtis AM, Boston RC, Panda S, Hogenesch JB, FitzGerald GA: BMAL1 and CLOCK, two essential components of the circadian clock, are involved in glucose homeostasis. PLoS Biol 2004;2:e377.

48 Yang S, Liu A, Weidenhammer A, Cooksey RC, McClain D, Kim MK, Aguilera G, Abel ED, Chung JH: The role of mPer2 clock gene in glucocorticoid and feeding rhythms. Endocrinology 2009;150:2153-2160.

49 Grimaldi B, Bellet MM, Katada S, Astarita G, Hirayama J, Amin RH, Granneman JG, Piomelli D, Leff T, Sassone-Corsi P: PER2 controls lipid metabolism by direct regulation of PPARgamma. Cell Metab 2010;12:509-520.

50 Shi SQ, Ansari TS, McGuinness OP, Wasserman DH, Johnson CH: Circadian disruption leads to insulin resistance and obesity. Curr Biol 2013;23:372-381.

51 Maury E, Ramsey KM, Bass J: Circadian rhythms and metabolic syndrome: from experimental genetics to human disease. Circ Res 2010;106:447-462.

52 Yang X, Downes M, Yu RT, Bookout AL, He W, Straume M, Mangelsdorf DJ, Evans RM: Nuclear receptor expression links the circadian clock to metabolism. Cell 2006;126:801810.

53 Buijs RM, Scheer FA, Kreier F, Yi C, Bos N, Goncharuk VD, Kalsbeek A: Organization of circadian functions: interaction with the body. Prog Brain Res 2006;153:341-360.

54 Coomans CP, van den Berg SA, Lucassen EA, Houben T, Pronk AC, van der Spek RD, Kalsbeek A, Biermasz NR, Willems van DK, Romijn JA, Meijer JH: The suprachiasmatic nucleus controls circadian energy metabolism and hepatic insulin sensitivity. Diabetes 2013;62:1102-1108.

55 la Fleur SE, Kalsbeek A, Wortel J, van der Vliet J, Buijs RM: Role for the pineal and melatonin in glucose homeostasis: pinealectomy increases night-time glucose concentrations. J Neuroendocrinol 2001;13:1025-1032.

56 la Fleur SE, Kalsbeek A, Wortel J, Fekkes ML, Buijs RM: A daily rhythm in glucose tolerance: a role for the suprachiasmatic nucleus. Diabetes 2001;50:1237-1243.

57 Monteleone P, Tortorella A, Docimo L, Maldonato MN, Canestrelli B, De LL, Maj M: Investigation of $3111 \mathrm{~T} / \mathrm{C}$ polymorphism of the CLOCK gene in obese individuals with or without binge eating disorder: association with higher body mass index. Neurosci Lett 2008;435:30-33.

58 Garaulet M, Corbalan MD, Madrid JA, Morales E, Baraza JC, Lee YC, Ordovas JM: CLOCK gene is implicated in weight reduction in obese patients participating in a dietary programme based on the Mediterranean diet. Int J Obes (Lond) 2010;34:516-523.

59 Ye D, Cai S, Jiang X, Ding Y, Chen K, Fan C, Jin M: Associations of polymorphisms in circadian genes with abdominal obesity in Chinese adult population. Obes Res Clin Pract 2016;10(suppl 1):S133-S141. 
60 Bouatia-Naji N, Bonnefond A, CavalcantiProenca C, Sparso T, Holmkvist J, Marchand M, Delplanque J, Lobbens S, Rocheleau G, Durand E, De Graeve F, Chevre JC, BorchJohnsen K, Hartikainen AL, Ruokonen A, Tichet J, Marre M, Weill J, Heude B, Tauber M, Lemaire K, Schuit F, Elliott P, Jorgensen T, Charpentier G, Hadjadj S, Cauchi S, Vaxillaire M, Sladek R, Visvikis-Siest S, Balkau B, Levy-Marchal C, Pattou F, Meyre D, Blakemore AI, Jarvelin MR, Walley AJ, Hansen T, Dina C, Pedersen O, Froguel P: A variant near MTNR1B is associated with increased fasting plasma glucose levels and type 2 diabetes risk. Nat Genet 2009;41:89-94.

61 Prokopenko I, Langenberg C, Florez JC, Saxena $\mathrm{R}$, et al: Variants in MTNR1B influence fasting glucose levels. Nat Genet 2009;41:7781.

62 Lyssenko V, Nagorny CL, Erdos MR, Wierup N, Jonsson A, Spegel P, Bugliani M, Saxena R, Fex M, Pulizzi N, Isomaa B, Tuomi T, Nilsson P, Kuusisto J, Tuomilehto J, Boehnke M, Altshuler D, Sundler F, Eriksson JG, Jackson AU, Laakso M, Marchetti P, Watanabe RM, Mulder H, Groop L: Common variant in MTNR1B associated with increased risk of type 2 diabetes and impaired early insulin secretion. Nat Genet 2009;41:82-88.

63 Bonnefond A, Clement N, Fawcett K, Yengo L, Vaillant E, Guillaume JL, Dechaume A, Payne F, Roussel R, Czernichow S, Hercberg S, Hadjadj S, Balkau B, Marre M, Lantieri O, Langenberg C, Bouatia-Naji N, Charpentier G, Vaxillaire M, Rocheleau G, Wareham NJ, Sladek R, McCarthy MI, Dina C, Barroso I, Jockers R, Froguel P: Rare MTNR1B variants impairing melatonin receptor $1 \mathrm{~B}$ function contribute to type 2 diabetes. Nat Genet 2012; 44:297-301.

64 Salman M, Dasgupta S, Cholendra A, Venugopal PN, Lakshmi GL, Xaviour D, Rao J, D'Souza CJ: MTNR1B gene polymorphisms and susceptibility to type 2 diabetes: a pilot study in South Indians. Gene 2015;566:189193.

$65 \mathrm{Hu} \mathrm{C}$, Jia W: Linking MTNR1B variants to diabetes: the role of circadian rhythms. Diabetes 2016;65:1490-1492.

66 Yamaguchi M, Uemura H, Arisawa K, Katsuura-Kamano S, Hamajima N, Hishida A, Suma S, Oze I, Nakamura K, Takashima N, Suzuki S, Ibusuki R, Mikami H, Ohnaka K, Kuriyama N, Kubo M, Tanaka H: Association between brain-muscle-ARNT-like protein-2 (BMAL2) gene polymorphism and type 2 diabetes mellitus in obese Japanese individuals: a cross-sectional analysis of the Japan MultiInstitutional Collaborative Cohort Study Diabetes. Res Clin Pract 2015;110:301-308.

67 Corella D, Asensio EM, Coltell O, Sorli JV, Estruch R, Martinez-Gonzalez MA, Salas-Salvado J, Castaner O, Aros F, Lapetra J, SerraMajem L, Gomez-Gracia E, Ortega-Azorin C, Fiol M, Espino JD, Diaz-Lopez A, Fito M, Ros $\mathrm{E}$, Ordovas JM: CLOCK gene variation is associated with incidence of type- 2 diabetes and cardiovascular diseases in type-2 diabetic subjects: dietary modulation in the PREDIMED randomized trial. Cardiovasc Diabetol 2016; 15:4.

68 Fonken LK, Nelson RJ: The effects of light at night on circadian clocks and metabolism. Endocr Rev 2014;35:648-670.

69 Hatori M, Vollmers C, Zarrinpar A, DiTacchio L, Bushong EA, Gill S, Leblanc M, Chaix A, Joens M, Fitzpatrick JA, Ellisman MH, Panda S: Time-restricted feeding without reducing caloric intake prevents metabolic diseases in mice fed a high-fat diet. Cell Metab 2012;15:848-860.

70 McFadden E, Jones ME, Schoemaker MJ, Ashworth A, Swerdlow AJ: The relationship between obesity and exposure to light at night: cross-sectional analyses of over 100,000 women in the Breakthrough Generations Study. Am J Epidemiol 2014;180:245-250.

71 Burdelak W, Peplonska B: Night work and health of nurses and midwives - a review (in Polish). Med Pr 2013;64:397-418.

72 Qin LQ, Li J, Wang Y, Wang J, Xu JY, Kaneko $\mathrm{T}$ : The effects of nocturnal life on endocrine circadian patterns in healthy adults. Life Sci 2003;73:2467-2475.

73 Nguyen J, Wright KP Jr: Influence of weeks of circadian misalignment on leptin levels. Nat Sci Sleep 2009;2010:9-18.

74 Salgado-Delgado R, Angeles-Castellanos M, Buijs MR, Escobar C: Internal desynchronization in a model of night-work by forced activity in rats. Neuroscience 2008; 154:922931.

75 Salgado-Delgado RC, Saderi N, Basualdo MC, Guerrero-Vargas NN, Escobar C, Buijs RM: Shift work or food intake during the rest phase promotes metabolic disruption and desynchrony of liver genes in male rats. PLoS One 2013;8:e60052.

76 Grosbellet E, Dumont S, Schuster-Klein C, Guardiola-Lemaitre B, Pevet P, Criscuolo F, Challet E: Circadian phenotyping of obese and diabetic $\mathrm{db} / \mathrm{db}$ mice. Biochimie 2016;124: 198-206.

77 Grosbellet E, Gourmelen S, Pevet P, Criscuolo F, Challet E: Leptin normalizes photic synchronization in male ob/ob mice, via indirect effects on the suprachiasmatic nucleus. Endocrinology 2015;156:1080-1090.

78 Grosbellet E, Dumont S, Schuster-Klein C, Guardiola-Lemaitre B, Pevet P, Criscuolo F, Challet E: Leptin modulates the daily rhythmicity of blood glucose. Chronobiol Int 2015; 32:637-649.

79 Salgado-Delgado R, Nadia S, Angeles-Castellanos M, Buijs RM, Escobar C: In a rat model of night work, activity during the normal resting phase produces desynchrony in the hypothalamus. J Biol Rhythms 2010;25:421-431.

80 Salgado-Delgado R, Angeles-Castellanos M, Saderi N, Buijs RM, Escobar C: Food intake during the normal activity phase prevents obesity and circadian desynchrony in a rat model of night work. Endocrinology 2010; 151:1019-1029.
81 Yasumoto Y, Hashimoto C, Nakao R, Yamazaki H, Hiroyama H, Nemoto T, Yamamoto S, Sakurai M, Oike H, Wada N, Yoshida-Noro C, Oishi K: Short-term feeding at the wrong time is sufficient to desynchronize peripheral clocks and induce obesity with hyperphagia, physical inactivity and metabolic disorders in mice. Metabolism 2016;65:714-727.

82 Pijut SS, Corbett DE, Wang Y, Li J, Charnigo RJ, Graf GA: Effect of peripheral circadian dysfunction on metabolic disease in response to a diabetogenic diet. Am J Physiol Endocrinol Metab 2016;310:E900-E911.

83 Rakshit K, Hsu TW, Matveyenko AV: Bmal1 is required for beta cell compensatory expansion, survival and metabolic adaptation to diet-induced obesity in mice. Diabetologia 2016;59:734-743.

84 Pivovarova O, Gogebakan O, Sucher S, Groth J, Murahovschi V, Kessler K, Osterhoff M, Rudovich N, Kramer A, Pfeiffer AF: Regulation of the clock gene expression in human adipose tissue by weight loss. Int $\mathrm{J}$ Obes (Lond) 2016;40:899-906.

85 Costa Justus JF, Ligocki Campos AC, Figueroa AL, Gomis R, Santo MA, Favero GM, Milleo FQ, Vieira E: Early effect of bariatric surgery on the circadian rhythms of adipokines in morbidly obese women. Metab Syndr Relat Disord 2016;14:16-22.

86 Smith J, Fahrenkrug J, Jorgensen HL, Christoffersen C, Goetze JP: Diurnal gene expression of lipolytic natriuretic peptide receptors in white adipose tissue. Endocr Connect 2015; 4:206-214.

87 Genzer Y, Dadon M, Burg C, Chapnik N, Froy $\mathrm{O}$ : Effect of dietary fat and the circadian clock on the expression of brain-derived neurotrophic factor (BDNF). Mol Cell Endocrinol 2016;430:49-55.

88 Nakahata Y, Kaluzova M, Grimaldi B, Sahar S, Hirayama J, Chen D, Guarente LP, SassoneCorsi P: The NAD+-dependent deacetylase SIRT1 modulates CLOCK-mediated chromatin remodeling and circadian control. Cell 2008; 134:329-340.

89 Nakahata Y, Sahar S, Astarita G, Kaluzova M, Sassone-Corsi P: Circadian control of the NAD+ salvage pathway by CLOCK-SIRT1. Science 2009;324:654-657.

90 Ramsey KM, Yoshino J, Brace CS, Abrassart D, Kobayashi Y, Marcheva B, Hong HK, Chong JL, Buhr ED, Lee C, Takahashi JS, Imai S, Bass J: Circadian clock feedback cycle through NAMPT-mediated NAD+ biosynthesis. Science 2009;324:651-654.

91 Asher G, Gatfield D, Stratmann M, Reinke H, Dibner C, Kreppel F, Mostoslavsky R, Alt FW, Schibler U: SIRT1 regulates circadian clock gene expression through PER2 deacetylation. Cell 2008; 134:317-328.

92 Alenghat T, Meyers K, Mullican SE, Leitner K, Adeniji-Adele A, Avila J, Bucan M, Ahima RS, Kaestner KH, Lazar MA: Nuclear receptor corepressor and histone deacetylase 3 govern circadian metabolic physiology. Nature 2008; 456:997-1000. 
93 Feng D, Liu T, Sun Z, Bugge A, Mullican SE, Alenghat T, Liu XS, Lazar MA: A circadian rhythm orchestrated by histone deacetylase 3 controls hepatic lipid metabolism. Science 2011;331:1315-1319.

94 Milagro FI, Gomez-Abellan P, Campion J, Martinez JA, Ordovas JM, Garaulet M: CLOCK, PER2 and BMAL1 DNA methylation: association with obesity and metabolic syndrome characteristics and monounsaturated fat intake. Chronobiol Int 2012;29: 1180-1194.

95 Samblas M, Milagro FI, Gomez-Abellan P, Martinez JA, Garaulet M: Methylation on the circadian gene BMAL1 is associated with the effects of a weight loss intervention on serum lipid levels. J Biol Rhythms 2016;31: 308-317.

96 Cano BP, Pagano ES, Jimenez-Ortega V, Fernandez-Mateos P, Esquifino AI, Cardinali DP: Melatonin normalizes clinical and biochemical parameters of mild inflammation in diet-induced metabolic syndrome in rats. J Pineal Res 2014;57:280-290.

97 Mendez I, Vazquez-Martinez O, Hernandez-Munoz R, Valente-Godinez H, DiazMunoz M: Redox regulation and pro-oxidant reactions in the physiology of circadian systems. Biochimie 2016;124:178-186.

98 Arora T, Taheri S: Sleep optimization and diabetes control: a review of the literature. Diabetes Ther 2015;6:425-468.

99 Arora T, Chen MZ, Cooper AR, Andrews RC, Taheri S: The impact of sleep debt on excess adiposity and insulin sensitivity in patients with early type 2 diabetes mellitus. J Clin Sleep Med 2016;12:673-680.

100 Arora T, Chen MZ, Omar OM, Cooper AR, Andrews RC, Taheri S: An investigation of the associations among sleep duration and quality, body mass index and insulin resistance in newly diagnosed type 2 diabetes mellitus patients. Ther Adv Endocrinol Metab 2016;7:3-11.

101 Valladares M, Obregon AM, Chaput JP: Association between genetic variants of the clock gene and obesity and sleep duration. J Physiol Biochem 2015;71:855-860.

102 Damiola F, Le MN, Preitner N, Kornmann B, Fleury-Olela F, Schibler U: Restricted feeding uncouples circadian oscillators in peripheral tissues from the central pacemaker in the suprachiasmatic nucleus. Genes Dev 2000; 14:2950-2961.

103 Hirao A, Tahara Y, Kimura I, Shibata S: A balanced diet is necessary for proper entrainment signals of the mouse liver clock. PLoS One 2009;4:e6909.

104 Kuroda H, Tahara Y, Saito K, Ohnishi N, Kubo Y, Seo Y, Otsuka M, Fuse Y, Ohura Y, Hirao A, Shibata S: Meal frequency patterns determine the phase of mouse peripheral circadian clocks. Sci Rep 2012;2:711.

105 Itokawa $\mathrm{M}$, Hirao A, Nagahama H, Otsuka M, Ohtsu T, Furutani N, Hirao K, Hatta T, Shibata S: Time-restricted feeding of rapidly digested starches causes stronger en- trainment of the liver clock in PER2:: LUCIFERASE knock-in mice. Nutr Res 2013;33:109-119.

106 Oike H, Nagai K, Fukushima T, Ishida N, Kobori M: Feeding cues and injected nutrients induce acute expression of multiple clock genes in the mouse liver. PLoS One 2011;6:e23709.

107 Oike H, Kobori M, Suzuki T, Ishida N: Caffeine lengthens circadian rhythms in mice. Biochem Biophys Res Commun 2011;410: 654-658.

108 Oike H, Nagai K, Fukushima T, Ishida N, Kobori M: High-salt diet advances molecular circadian rhythms in mouse peripheral tissues. Biochem Biophys Res Commun 2010;402:7-13.

109 Oike H, Kobori M: Resveratrol regulates circadian clock genes in Rat-1 fibroblast cells. Biosci Biotechnol Biochem 2008;72:30383040.

110 Kohsaka A, Laposky AD, Ramsey KM, Estrada C, Joshu C, Kobayashi Y, Turek FW, Bass J: High-fat diet disrupts behavioral and molecular circadian rhythms in mice. Cell Metab 2007;6:414-421.

111 Eckel-Mahan KL, Patel VR, de MS, OrozcoSolis R, Ceglia NJ, Sahar S, Dilag-Penilla SA, Dyar KA, Baldi P, Sassone-Corsi P: Reprogramming of the circadian clock by nutritional challenge. Cell 2013;155:14641478.

112 Pendergast JS, Branecky KL, Yang W, Ellacott KL, Niswender KD, Yamazaki S: Highfat diet acutely affects circadian organisation and eating behavior. Eur J Neurosci 2013;37: 1350-1356.

113 Branecky KL, Niswender KD, Pendergast JS Disruption of daily rhythms by high-fat diet is reversible. PLoS One 2015;10:e137970.

114 Sherman H, Genzer Y, Cohen R, Chapnik N, Madar Z, Froy O: Timed high-fat diet resets circadian metabolism and prevents obesity. FASEB J 2012;26:3493-3502.

115 Hariri N, Thibault L: Dietary obesity caused by a specific circadian eating pattern. Chronobiol Int 2011;28:216-228.

116 Jakubowicz D, Barnea M, Wainstein J, Froy O: High caloric intake at breakfast vs. dinner differentially influences weight loss of overweight and obese women. Obesity (Silver Spring) 2013;21:2504-2512.

117 Garvey WT, Garber AJ, Mechanick JI, Bray GA, Dagogo-Jack S, Einhorn D, Grunberger G, Handelsman Y, Hennekens CH, Hurley DL, McGill J, Palumbo P, Umpierrez G, on Behalf of The Aace Obesity Scientific Committee: American Association of Clinical Endocrinologists and American College of Endocrinology position statement on the 2014 advanced framework for a new diagnosis of obesity as a chronic disease. Endocr Pract 2014;20:977-989.

118 Garvey WT, Garber AJ, Mechanick JI, Bray GA, Dagogo-Jack S, Einhorn D, Grunberger G, Handelsman Y, Hennekens CH, Hurley DL, McGill J, Palumbo P, Umpierrez G, on
Behalf of The Aace Obesity Scientific Committee: American Association of Clinical Endocrinologists and American College of Endocrinology consensus conference on obesity: building an evidence base for comprehensive action. Endocr Pract 2014;20: 956-976.

119 Garber AJ, Abrahamson MJ, Barzilay JI, Blonde L, Bloomgarden ZT, Bush MA, Dagogo-Jack S, Davidson MB, Einhorn D, Garber JR, Garvey WT, Grunberger G, Handelsman Y, Hirsch IB, Jellinger PS, McGill JB, Mechanick JI, Rosenblit PD, Umpierrez G, Davidson MH: Aace/Ace comprehensive diabetes management algorithm 2015. Endocr Pract 2015;21:438-447.

120 Jensen MD, Ryan DH, Apovian CM, Ard JD, Comuzzie AG, Donato KA, Hu FB, Hubbard VS, Jakicic JM, Kushner RF, Loria CM, Millen BE, Nonas CA, Pi-Sunyer FX, Stevens J, Stevens VI, Wadden TA, Wolfe BM, Yanovski SZ: 2013 AHA/ACC/TOS guideline for the management of overweight and obesity in adults: a report of the American College of Cardiology/American Heart Association Task Force on Practice Guidelines and The Obesity Society. J Am Coll Cardiol 2014; 63:2985-3023.

121 Apovian CM, Aronne LJ, Bessesen DH, McDonnell ME, Murad MH, Pagotto U, Ryan DH, Still CD: Pharmacological management of obesity: an endocrine Society clinical practice guideline. J Clin Endocrinol Metab 2015; 100:342-362.

122 Look AHEAD Research Group: Eight-year weight losses with an intensive lifestyle intervention: the look AHEAD study. Obesity (Silver Spring) 2014;22:5-13.

123 Fujioka K: Safety and tolerability of medications approved for chronic weight management. Obesity (Silver Spring) 2015;23 (suppl 1):S7-S11.

124 Inge TH, Krebs NF, Garcia VF, Skelton JA, Guice KS, Strauss RS, Albanese CT, Brandt ML, Hammer LD, Harmon CM, Kane TD, Klish WJ, Oldham KT, Rudolph CD, Helmrath MA, Donovan E, Daniels SR: Bariatric surgery for severely overweight adolescents: concerns and recommendations. Pediatrics 2004;114:217-223.

125 Tsai WS, Inge TH, Burd RS: Bariatric surgery in adolescents: recent national trends in use and in-hospital outcome. Arch Pediatr Adolesc Med 2007;161:217-221.

126 Benaiges D, Goday A, Pedro-Botet J, Mas A, Chillaron JJ, Flores-Le Roux JA: Bariatric surgery: to whom and when? Minerva Endocrinol 2015;40:119-128.

127 Bult MJ, van DT, Muller AF: Surgical treatment of obesity. Eur J Endocrinol 2008; 158 : 135-145.

128 Busetto L, Dixon J, De LM, Shikora S, Pories W, Angrisani L: Bariatric surgery in class I obesity : a Position Statement from the International Federation for the Surgery of Obesity and Metabolic Disorders (IFSO). Obes Surg 2014;24:487-519. 
129 Courcoulas AP, Christian NJ, Belle SH, Berk PD, Flum DR, Garcia L, Horlick M, Kalarchian MA, King WC, Mitchell JE, Patterson EJ, Pender JR, Pomp A, Pories WJ, Thirlby RC, Yanovski SZ, Wolfe BM: Weight change and health outcomes at 3 years after bariatric surgery among individuals with severe obesity. JAMA 2013;310:2416-2425.

130 Gloy VL, Briel M, Bhatt DL, Kashyap SR, Schauer PR, Mingrone G, Bucher HC, Nordmann AJ: Bariatric surgery versus nonsurgical treatment for obesity: a systematic review and meta-analysis of randomised controlled trials. BMJ 2013;347:f5934.

131 Colquitt JL, Pickett K, Loveman E, Frampton GK: Surgery for weight loss in adults. Cochrane Database Syst Rev 2014;8: CD003641.

132 Schauer PR, Bhatt DL, Kashyap SR: Bariatric surgery versus intensive medical therapy for diabetes. N Engl J Med 2014;371:682.

133 Gonzalez-Campoy JM, St Jeor ST, Castorino K, Ebrahim A, Hurley D, Jovanovic L, Mechanick JI, Petak SM, Yu YH, Harris KA, Kris-Etherton P, Kushner R, Molini-Blandford M, Nguyen QT, Plodkowski R, Sarwer DB, Thomas KT: Clinical practice guidelines for healthy eating for the prevention and treatment of metabolic and endocrine diseases in adults: cosponsored by the American Association of Clinical Endocrinologists/the American College of Endocrinology and the Obesity Society: executive summary. Endocr Pract 2013;19:875-887.

134 Fujioka K, DiBaise JK, Martindale RG: Nutrition and metabolic complications after bariatric surgery and their treatment JPEN. J Parenter Enteral Nutr 2011;35:52S-59S.

135 Angrisani L, Santonicola A, Iovino P, Formisano G, Buchwald H, Scopinaro N: Bariatric surgery worldwide 2013. Obes Surg 2015;25: 1822-1832.

136 Apovian CM, Garvey WT, Ryan DH: Challenging obesity: patient, provider, and expert perspectives on the roles of available and emerging nonsurgical therapies. Obesity (Silver Spring) 2015;23:S1-S26.

137 Scheer FA, Hilton MF, Mantzoros CS, Shea SA: Adverse metabolic and cardiovascular consequences of circadian misalignment. Proc Natl Acad Sci USA 2009;106:44534458.
138 Marcheva B, Ramsey KM, Bass J: Circadian genes and insulin exocytosis Cell Logist 2011;1:32-36.

139 Garaulet M, Madrid JA: Chronobiology, genetics and metabolic syndrome. Curr Opin Lipidol 2009;20:127-134.

140 Arendt J, Skene DJ: Melatonin as a chronobiotic. Sleep Med Rev 2005;9:25-39.

141 Cardinali D: Melatonin as a chronobioticcytoprotective agent in sleep disorders; in Parmeggiani P, Velluti R (eds): The Physiological Nature of Sleep. London, Imperial College Press, 2005.

142 Touitou Y, Bogdan A: Promoting adjustment of the sleep-wake cycle by chronobiotics. Physiol Behav 2007;90:294-300.

143 Cardinali DP, Pagano ES, Scacchi Bernasconi PA, Reynoso R, Scacchi P: Disrupted chronobiology of sleep and cytoprotection in obesity: possible therapeutic value of melatonin. Neuroendocrinol Lett 2011;32:588606.

144 Tan DX, Manchester LC, Fuentes-Broto L, Paredes SD, Reiter RJ: Significance and application of melatonin in the regulation of brown adipose tissue metabolism: relation to human obesity. Obes Rev 2011;12:167188.

145 Cardinali DP, Bernasconi PA, Reynoso R, Toso CF, Scacchi P: Melatonin may curtail the metabolic syndrome: studies on initial and fully established fructose-induced metabolic syndrome in rats. Int J Mol Sci 2013;14: 2502-2514.

146 Kozirog M, Poliwczak AR, Duchnowicz P, Koter-Michalak M, Sikora J, Broncel M: Melatonin treatment improves blood pressure, lipid profile, and parameters of oxidative stress in patients with metabolic syndrome. J Pineal Res 2011;50:261-266.

147 Gonciarz M, Bielanski W, Partyka R, Brzozowski T, Konturek PC, Eszyk J, Celinski K, Reiter RJ, Konturek SJ: Plasma insulin, leptin, adiponectin, resistin, ghrelin, and melatonin in nonalcoholic steatohepatitis patients treated with melatonin. J Pineal Res 2013;54:154-161.
148 Gonciarz M, Gonciarz Z, Bielanski W, Mularczyk A, Konturek PC, Brzozowski T, Konturek SJ: The effects of long-term melatonin treatment on plasma liver enzymes levels and plasma concentrations of lipids and melatonin in patients with nonalcoholic steatohepatitis: a pilot study J Physiol Pharmacol 2012;63:35-40.

149 Romo-Nava F, Alvarez-Icaza GD, FresanOrellana A, Saracco AR, Becerra-Palars C, Moreno J, Ontiveros Uribe MP, Berlanga C, Heinze G, Buijs RM: Melatonin attenuates antipsychotic metabolic effects: an eightweek randomized, double-blind, parallelgroup, placebo-controlled clinical trial. Bipolar Disord 2014;16:410-421.

150 Modabbernia A, Heidari P, Soleimani R, Sobhani A, Roshan ZA, Taslimi S, Ashrafi M, Modabbernia MJ: Melatonin for prevention of metabolic side-effects of olanzapine in patients with first-episode schizophrenia: randomized double-blind placebo-controlled study. J Psychiatr Res 2014;53:133140.

151 Cardinali DP, Srinivasan V, Brzezinski A, Brown GM: Melatonin and its analogs in insomnia and depression. J Pineal Res 2012;52: 365-375.

152 Weishaupt JH, Bartels C, Polking E, Dietrich J, Rohde G, Poeggeler B, Mertens N, Sperling S, Bohn M, Huther G, Schneider A, Bach A, Siren AL, Hardeland R, Bahr M, Nave KA, Ehrenreich $\mathrm{H}$ : Reduced oxidative damage in ALS by high-dose enteral melatonin treatment. J Pineal Res 2006;41:313-323.

153 Gagliardino JJ: Physiological endocrine control of energy homeostasis and postprandial blood glucose levels. Eur Rev Med Pharmacol Sci 2005;9:75-92.

154 Cusi K: The role of adipose tissue and lipotoxicity in the pathogenesis of type 2 diabetes. Curr Diab Rep 2010;10:306-315.

155 Norman D, Isidori AM, Frajese V, Caprio M, Chew SL, Grossman AB, Clark AJ, Michael Besser G, Fabbri A: ACTH and alphaMSH inhibit leptin expression and secretion in 3T3-L1 adipocytes: model for a centralperipheral melanocortin-leptin pathway. Mol Cell Endocrinol 2003;200:99-109. 